\title{
Research on Talent Cultivation Pattern of Chinese-Foreign Cooperation
}

\author{
Nianyu Zou, Ping Li, Yuncui Zhang, Yi Yang, Yingming Gao \\ Dalian Polytechnic University, School of Information Science and Engineering, Dalian, 116034
}

\begin{abstract}
This paper introduces light source and lighting professional of Dalian Polytechnic University in recent years which has obtained many achievements such as the complementary of resource of teacher's professional, the cultivation of students' innovation ability, social benefits, the employment of students according to the demand of the subject development, through the introduction of talents and exchanges of visits and other substantive international cooperation from overseas team, a new approach of light source and lighting professional has been explored about personnel training.
\end{abstract}

Index Terms - Chinese-Foreign cooperation, personnel training, Light source and lighting professional

\section{Introduction}

With the rapid development of economy and increasingly high degree of informatization today, information technology is becoming leap development and penetrates into all areas. Besides electronic information industry is a pillar industry of the world which is scrambling to develop and is the main force of fierce competition and the most rapid development of high-tech industries. The rapid development in global industry leads to increasingly fierce competition for talent, which presents higher and higher requirements for the teaching form of high schools and personnel training. However, what the colleges in the province did more in the past was something about teaching material construction, course construction, the improvement of teaching methods and other aspects. The forms of overseas scholars visiting schools and communicating with students are often limited to an academic report, lacking of more widely substantial technical exchange.

In order to fully improve the quality of higher education, improve the quality of personnel training, deepen teaching reform and strengthen the international competitiveness of higher education, it's the only route which must be passed to explore the mode of sino-foreign cooperation in personnel training. So it is a significantly meaningful topic to talk about how to put the advantages and characteristics of ChineseForeign cooperation in personnel training into the mode of applied talents training organically.

\section{Analysis of Current Situation}

Light source and lighting in Dalian Polytechnic University has a solid discipline basis in the field of optoelectronics, the main research directions include: 1.Research about photonic device and related technology facing a new generation of optical communication system, including the design of new type of optical fiber, optical fiber and optical system testing, optical fiber subscriber network monitoring technology, development of new functional laset source, optical sensing, optical amplification technology and the study of quantum communication and quantum information; 2. Research on new photoelectric and lighting technology and optical system ,including organic lightemitting materials, new display devices, optical design and system development, design and optimization of optical system and the detection and evaluation of all kinds of devices and systems.etc...Dalian Polytechnic University is the only university in Dalian and northeast area. which sets photoelectric lighting technology for undergraduate professional direction, which has in resent years cultivated and transported a large number of lighting professionals for our country.

Light source and lighting in Dalian Polytechnic University undertakes an important task of building in the field of semiconductor lighting: 1. Take the construction of Dalian semiconductor lighting detection platform.. 2. Assume the test evaluation of semiconductor lighting demonstration project of Dalian development zone. It provides an information communication and exchange platform for the entire semiconductor lighting industry , and assists enterprise to release information, questionaire investigation and personnel training and so on, attracting more domestic and foreign enterprise into the development zone.3.Server as the unit of vice director of the semiconductor industry technology innovation alliance of Dalian and the unit of deputy director of lighting association in Liaoning Province, which plays a vital role in the whole semiconduct industry alliance, and develops the advantage of the University in the alliance, forming the Dalian semiconductor industry cluster as a whole.4.Take semiconductor lighting engineering labotatary in Dalian. It systemically carries on exploring test method, test equipment and test standard and studying on new technology and new method; and it step by step constructs high levels of teating and evaluating system and the field detection scheme of photometry, colorimetry, electrical, life and reliability, environmental adaptability and other characteristics of light source for various uses and lighting lamps(including other lighting lamps led by LED).

Light source and lighting professional establishes international cooperation relationship extensively. the Japanese National Institute of University of the Ryukyus) in recent years. our school developed academic exchanges with professors and students at higher institute from Japan, French, the Harbin Institute of Technology, Jilin University, Beijing University of Posts and Telecommunications, the Chinese Academy of Sciences Institute of chemistry and physics, and 
graduate students got plenty of exercise from this. In order to better develop international exchanges and cooperation, our team and the Japanese National Institute of University of the Ryukyus have set up a joint laboratory, and carried on personnel exchange and mutual research. As one of the series of exchanges, in 2009, Dr. Feroza Begum from Japanese University of the Ryukyus joined our team and worked for a year. Foreign teachers directly involved in teaching and research section activities, and attended the guidance of graduation design and graduation design of undergraduate work of the respondent, and carried on academic discussio and research with teachers from electronic information professional in our school, providing helpful guidance for students to broaden their horizons. Graduates and teachers from two universities have published many academic papers and made gratifying achievements. In 2011,LED lighting meeting among three countries, China, Japan and South Korea, was held in Dalian. Research Institute of Photonics serving as the organizer has gained praise. The activity of international communication not only built a broad platform for teachers and students to research and explore new task, but also created favorable conditions for teachers and students to promote scientific research ability of practice.

\section{The Main Contents of Research}

Research Institute of Photonics, using international cooperation and exchange and resource what we have owned, attracts actively teaching and research team from overseas directly participating in the training of undergraduates and graduates, transports compound talents who have solid professional basis, good ability to innovate and open international vision., and fully develops internationalization advantages of our school faculty, and then builds Sino foreign cooperative platform of Light source and lighting professional about talent training.

Take the student as the main body of the diversified international cooperation. The main purpose of teaching reform is to serve the students; the adjust of students automatic, initiative is an effective means to cultivate students' ability. We pay more attention to the role of students in teaching reform and support students to participate in international conferences and international exchange. In the past, Light source and lighting professional held many activities such as students innovation project, international conferences and exchange of international teachers and students, and in these activities students attended directly the preparation, the communication in the meeting, results sorting, exercising students' working ability and cultivating students' vision of surpassing national boundaries. It's significantly meaningful for students to establish a correct concept of scientific research, enhance the professional interest of scientific research on lighting and the future growth of students.

Take international laboratory as cooperation platform. Driving force for cooperation of Chinese and foreign teaching department of scientific research cooperation. We should closely seize the key role of scientific research projects in teaching reform and establish organic relation with Chinese and foreign excellent resources and personnels in forms and substances, which can not only improve the professional construction level, but also ensure long-term development of cooperation.

\section{Preliminary Results}

1) Achieve the complementary of professional resource with foreign colleges. In 2009, our institute signed the academy level cooperation agreement with Japan's University of the Ryukyus, Northeastern University. Overseas team members directly guided the graduate design of undergraduates and won the title of excellent graduate design of our university. Professional teachers go out of the country and step into foreign universities to ersearch and exchange, introducing and absorbing advanced education and the methods of training students. Currently there are two teachers serving as visiting scholars at University of Washington in America. Our institute has hosted many international confetences.

2) The enhance of students' ability of innovation. Students have taken active part in technology innovation of college students and various technology innovation contests hosted by the state, province, city and school. More than twenty patents have been applied.

3) Social benefits. Our school is located in Dalian where is an important base city in the national optoelectronic industry; the implementation of project plays an impotant role in the revitalization of northeast old industrial base and Dalian photoelectric industrial construction; teaching team of light source and lighting professional have taken the construction of Dalian semiconductor lighting detection platform and undertaken the project of Dalian semiconductor lighting engineering laboratory. cultivating excellent talents who need to own creative consciousness, Innovation ability and international vision in light source and lighting of photoelectric technology based on these projects, which meets the strategy of economic development of our country and regions.

4) Graduates with high comprehensive quality, and with better social demand. Cresting a new mode of cultivating talents; the comprehensive quality of students in light source and lighting professional has been improved in an overall way. As graduates have high comprehensive quality and strong innovation ability, they are deeply welcomed by the employing units.

\section{Conclusions}

We will further strengthen the efforts to cooperate with foreign famous universities and academy of science in personnel training and take many measures such as funding more teachers and students to go abroad to attend international conferences, establishing the plan of overseas scholars to give lectures, holding international academic forum between undergraduates and postgraduates. We will broaden international vision of large teachers and students, and improve innovation ability and the scientific research 
level, making the international exchanges and cooperation provide strong support to the discipline construction, teaching and scientific research and personnel training, and social service, and then develop deeply international cooperation in the areas of teaching and research, continuously improving the level of school education and research, and speeding up the pace of constructing application oriented university with high level.

\section{Acknowledgements}

This paper would like to thank the following projects supporting: In 2011, the National Science and technology supporting program (2011BAE01B06); In 2011, Dalian Science and technology program (2011A12GX014), the education innovation projects of the Education Department of Liaoning province(Liao Fa [2010] No. 36), Liaoning Province Education Science "the 12th Five-year Plan" project decided (JG11DB030); In 2010,Liaoning Province ordinary higher education undergraduate teaching reform research item "relying on international cooperation project to cultivate innovative talents of multidisciplinary cross";Undergraduate key supporting major construction projects 2012 regular institutions of higher education in Liaoning Province (ZD201222).

\section{References}

[1] Nianyu Zou, Yunzui Zhang. The characteristic construction and personnel training of electronic information in Dalian Polytechnic of University. The teaching cooperation conference of the National College of electronic information science and Engineering Specialty in 2009:42-45.

[2] Ping Li, Nianyu Zou. Exploration and practice of Chinese and foreign cooperation personnel training mode of electronic information science and engineering. China Science \& Technology.2010(86):102-103

[3] Bin Ning. Innovative personnel training of high-level characteristic university. Chinese higher education research 2009-8(5) 